\title{
Factors Correlated with Willingness and Compliance to Pay National Health Insurance Premium in Jember Regency
}

\author{
Nazilla Ade Nurlia'), Bhisma Murti'), Didik Gunawan Tamtomo²) \\ 1)MastersProgram in Public Health, Universitas Sebelas Maret \\ 2)Faculty of Medicine,Universitas Sebelas Maret
}

\section{ABSTRACT}

Background: Fulfillment of premium collectivity is related to willingness and compliance to pay BPJS Kesehatan premiums. Increasing participation in the informal sector is not in line with compliance in paying BPJS Health premiums. This study aims to analyze the influence of factors of willingness and compliance to pay premiums for BPJS Kesehatan independent participants in Jember Regency.

Subjects and Method: This was a cross sectional study conducted in 31 sub-districts in Jember Regency, East Java, in July-September 2020. Sampling of 200 BPJS Kesehatan Mandiri participants was conducted using random sampling. The dependent variable is willingness to pay and compliance to pay the BPJS Health premium. The independent variables include education, income, willingness to pay, imitation of the referral group and number of family members. Data were collected using a questionnaire. Data were analyzed using multiple linear regression, multiple logistic regression and path analysis with Stata 16.

Results: Factors that affect the willingness to pay are education $(b=45531.18 ; 95 \% \mathrm{CI}=$ 35335.1 to $55727.26 ; \mathrm{p}<0.001)$ and $(\mathrm{b}=2.13$ units; $95 \% \mathrm{CI}=1.41$ to 2.86 ; $\mathrm{p}<0.001$ ), income $(b=17469 ; 95 \% \mathrm{CI}=7171.90$ to $27766.09 ; \mathrm{p}$ $<0.001)$, and $(\mathrm{b}=1.19 ; 95 \% \mathrm{CI}=0.46$ to $1.92 ; \mathrm{p}$ $<0.001)$. Compliance to pay is influenced by the willingness to pay factor $(\mathrm{b}=4.19 ; 95 \% \mathrm{CI}=$ 2.19 to $8.04 ; \mathrm{p}<0.001)$ and $(\mathrm{b}=0.64 ; 95 \% \mathrm{CI}=$ 0.02 to $1.27 ; \mathrm{p}=0.044$ ) with an average willingness to pay Rp 44,792, imitation of the reference group $(b=2.59 ; 95 \% \mathrm{CI}=1.39$ to $4.85 ; \mathrm{p}=$ $0.003)$ and $(\mathrm{b}=0.95 ; 95 \% \mathrm{CI}=0.33$ to $1.58 ; \mathrm{p}=$ $0.003)$ and the number of family members $(b=$ $1.90 ; 95 \% \mathrm{CI}=1.02$ to $3.56 ; \mathrm{p}=0.044$ ).

Conclusion: Willingness to pay premiums is directly affected by education and income. Compliance with premium payments is directly affected by willingness to pay, imitation of the referral group, and the number of family members.

Keywords: willingness to pay, paying compliance, social cognitive theory

\section{Correspondence:}

Nazilla Ade Nurlia.Masters Program in Public Health, Universitas Sebelas Maret. Jl. Ir. Sutami 36A, Surakarta 57126, Central Java. Email: nazillaade29@gmail.com. Mobile: +6281230004195 .

\section{Cite this as:}

Nurlia NA, Murti B, Tamtomo DG (Year). Factors Correlated with Willingness and Compliance to Pay National Health Insurance Premium in Jember Regency. J Health Policy Manage. 06(01): 35-47. https://doi.org/10.26911/thejhpm.2021.06.01.04.

\section{BACKGROUND}

Indonesia provides health care and protection through an insurance program that has been implemented since 2014. National Health Insurance (JKN) according to Presidential Regulation Number 32 of 2014 is health protection to provide health care benefits and protection in meeting basic health needs for participants who have pay premiums or premiums borne by the government which are organized nationally based on the principles of social insurance. The target of the Health Insurance (JK) program is a comprehensive national mem- 
Nurlia et al./ Willingness and Compliance to Pay National Health Insurance Premium

bership coverage in 2019 or Universal Health Coverage (UHC).

Health insurance is administered by a public legal entity with duties and responsibilities, namely the Social Security Administering Body (BPJS). In line with the Healthy Indonesia Program, the third pillar is that health insurance is mandatory and covers all Indonesian citizens, a legal entity, namely BPJS, was formed in 2013. BPJS Kesehatan applies several principles including mutual cooperation, public legal entities, mandatory membership, trust funds, and The results of the management of social security funds are used entirely for program development and for the benefit of participants (Mas'udin, 2017).

Based on data from BPJS Kesehatan, PPU coverage is 53,016,564 participants, PBPU coverage is $30,242,021$ participants and non-workers are 5,011,660 participants (BPJS Kesehatan, 2019). Meanwhile, the total population of Indonesia is estimated to reach around 260 million people per 2018. Based on this data, only about $83 \%$ of the total population in Indonesia has not been involved in the health insurance scheme and has not registered with the BPJS (Prakoso, 2020).

Based on BPJS Kesehatan data for Jember Regency in 2018, the total population in Jember Regency in 2018 was $2,440,714$ with a total membership of $1,500,328$ people. In addition, the number of JKN independent participants in Jember Regency until 2018 is 8,126 independent participants, 18,485 members of the TNI and retired TNI, 4,664 members of the National Police and retirees, as many as 87,408 members of the transfer of health insurance. This shows that the independent participants of the JKN program for Jember Regency, namely those who are included in the group of non-wage recipients, are still very few of all registered participants (Noormalasari \& Sandra, 2015).

It is not only mandatory for workers in the formal sector, but informal workers are also required to participate in BPJS Kesehatan. Participation in informal workers or PBPU is a major challenge in achieving the target coverage and sustainability of a social security system. Participants who are involved in the agriculture, forestry and fisheries sectors are also included in the PBPU category included in the voluntary premium (Nguyen \& Hoang, 2017).

PBPU or informal worker participants have greater potential or probability than category participants other than independent participants to not comply with BPJS Health premium payments.

Increasing participation is not in line with compliance in paying BPJS Health premiums. Compliance is obedience or disobedience to orders or rules, while compliance in paying premiums means the behavior of a person who is willing to pay the premium appropriately based on a predetermined time (Rosmanely, 2018). Willingness to pay is also closely related to compliance to pay premiums.

This study aims to analyze the factors that influence the willingness and compliance of paying premiums to the participants of the independent BPJS Kesehatan in Jember Regency.

\section{SUBJECTS AND METHOD}

\section{Study Design}

A cross sectional study was conducted in Jember, East Java, from July to September 2020.

\section{Population and Sample}

The population in this study included BPJS Kesehatan Mandiri participants in the PPU and PBPU categories in Jember Regency. The number of samples is 200 research 
subjects. Sampling was done using random sampling technique.

\section{Variables}

The dependent variable is willingness to pay premiums and compliance to pay premiums. The independent variables include education, income, willingness to pay, imitation of the referral group and number of family members.

\section{Operational Definition of Variables} Education is the highest level of education that the research subject has achieved. The data scale is categorical, and for the purposes of data analysis, the data is converted into a dichotomy with the criteria $\mathrm{o}=$ Low $(<$ Senior high school) $1=$ High ( $\geq$ Senior high school)

Income is the maximum wage received by research subjects after working within a period of one month during the month of research. The data scale is continuous, and for the purposes of data analysis, the data is converted into categorical with the criteria $\mathrm{o}=$ Low $(<$ IDR 2,170,917) $1=$ High $(\geq \operatorname{IDR}$ 2,170,917).

Willingness to pay is the participant's willingness to spend money to pay the BPJS Health premium. The measurement scale is continous.

Imitation of a referral group is an individual or group that is used as a reference reference by the research subject in obeying to pay the BPJS Health premium. The data scale is categorical, and for the purposes of data analysis, the data is converted into a dichotomy with the criteria $0=$ Weak and 1 $=$ Strong.

The number of family members is all family members of research subjects registered with BPJS Kesehatan. The data scale is continuous, and for the purposes of data analysis, the data is converted into categorical with the criteria $\mathrm{O}=$ Low $(\leq 2$ people) $1=$ High ( $\geq 3$ people).

\section{Data Analysis}

Univariate analysis was carried out to see the frequency distribution and percentage of characteristics of research subjects. Bivariate analysis was performed to determine the relationship between the dependent variable and the independent variable using the chi-square test. Multivariate analysis was performed using multiple linear regression analysis, multiple logistic and path analysis.

\section{Research Ethics}

Research ethics includes a submission sheet, anonymity, confidentiality, and ethical eligibility. The ethical feasibility in this study comes from the Health Research Ethics Committee of the Dr. Moewardi Hospital Surakarta with number 1275 / XI / HREC / 2020.

\section{RESULTS}

1. Characteristics of Study Subjects

The characteristics of research subjects based on the results of the study include age, gender, marital status, education level, occupation and type of participation. Table 4.1 shows that most of the BPJS Kesehatan independent participants aged $\geq 21$ years 58 years, it is about 184 people (92.0\%). The majority of research subjects were female, as many as 120 people (60\%). Characteristics of marital status, most of the BPJS Kesehatan Mandiri participants were married, as many as 145 people (72.5\%). Most of the education level of the BPJS Kesehatan independent participants, namely SHS, amounted to 86 people (43.0\%). Most of them are self-employed, as many as 54 people (27.0\%).The type of participation in the research subjects was PBPU as many as 110 people (55.0\%).

\section{Univariate Analysis}

The results of the descriptive statistical test of continuous data which in the research variables include age, number of family 
Nurlia et al./ Willingness and Compliance to Pay National Health Insurance Premium

members, income and willingness to pay

can be seen in table 2 as follows:

Table 1. Characteristics of Study Subjects

\begin{tabular}{llcc}
\hline Characteristics & \multicolumn{1}{c}{ Criteria } & Frequency (n) & Percentage (\%) \\
\hline Age & $\geq 21$ years - 58 years & 184 & 92.0 \\
Gender & 59 years & 16 & 8.0 \\
& Male & 80 & 40.0 \\
Marital Status & Female & 120 & 60.0 \\
& Single & 27 & 13.5 \\
& Married & 145 & 72.5 \\
& Widow & 16 & 8.0 \\
Education & Widower & 12 & 6.0 \\
& No formal education & 4 & 2.0 \\
& PS & 18 & 9.0 \\
& JHS & 32 & 16.0 \\
& SHS & 86 & 43.0 \\
Occupation & Diploma & 16 & 8.0 \\
& College & 44 & 22.0 \\
& College student & 7 & 3.5 \\
& Temporary employees & 11 & 5.5 \\
& General employees & 37 & 18.5 \\
Participation & Labor & 14 & 7.0 \\
& Repairman & 4 & 2.0 \\
& Farmer & 11 & 5.5 \\
& Fisherman & 6 & 3.0 \\
& Civil servants & 8 & 4.0 \\
& Entrepreneur & 54 & 27.0 \\
& Salaried Worker & 90 & 45.0 \\
& Non-Wage Workers & 110 & 55.0 \\
\hline & & &
\end{tabular}

Table 2 Distribution of variable frequencies in continuous

\begin{tabular}{lccccc}
\hline \multicolumn{1}{c}{ Variable } & N & Mean & SD & Min. & Max. \\
\hline Age (year) & 200 & 42.03 & 12.11 & 17 & 73 \\
The number of family & 200 & 2.85 & 1.24 & 1 & 6 \\
member (people) & & & & & \\
Income (rupiah) & 200 & $2,005,500$ & $1,573,619$ & 300,000 & $10,000,000$ \\
Willingness to pay (rupiah) & 200 & 44792.5 & $40,228.97$ & 0 & 160,000 \\
\hline
\end{tabular}

Table 2 shows the results of statistical tests for each variable. This study involved 200 research subjects in BPJS Kesehatan independent participants. The results of this study indicate that the age of the BPJS Kesehatan independent participants is 1773 years with a mean of 42.03 years. The variable average number of family members registered with BPJS Kesehatan Mandiri is 2.85 with a minimum of 1 family member and a maximum of 6 people. The lowest income from BPJS Kesehatan participants is Rp. 300,000 and the highest is $\mathrm{Rp}$ 10,000,000 with an average of $\mathrm{Rp}$ 2,005,500. The willingness to pay for BPJS Kesehatan Mandiri participants shows that the lowest value is $o$ and the highest value is $\mathrm{Rp}$. 160,000 with an average willingness to pay Rp. 44,792. 
Nurlia et al./ Willingness and Compliance to Pay National Health Insurance Premium

2. Univariate Analysis

The results of the descriptive statistical test of continuous data which in the research variables include age, number of family members, income and willingness to pay can be seen in table 2 as follows:

Table 3. Univariate Analysis (Dichotomy Data)

\begin{tabular}{|c|c|c|}
\hline Variable & $\mathbf{n}$ & $\%$ \\
\hline \multicolumn{3}{|l|}{ Age } \\
\hline Non productive & 16 & 8.0 \\
\hline Productive & 184 & 92.0 \\
\hline \multicolumn{3}{|l|}{ Education } \\
\hline$<$ SHS & 140 & 70.0 \\
\hline$\geq$ SHS & 60 & 30.0 \\
\hline \multicolumn{3}{|l|}{ Occupation } \\
\hline Informal & 155 & 77.5 \\
\hline Formal & 45 & 22.5 \\
\hline \multicolumn{3}{|l|}{ Income } \\
\hline$<$ minimum wage (Rp. 2,170,917) & 142 & 71.0 \\
\hline$\geq$ minimum wage (Rp. 2,170,917) & 58 & 29.0 \\
\hline \multicolumn{3}{|l|}{ Number of family member } \\
\hline Low & 80 & 40 \\
\hline High & 120 & 60 \\
\hline \multicolumn{3}{|l|}{ History of Illness } \\
\hline Seldom & 157 & 78.5 \\
\hline Often & 43 & 21.5 \\
\hline \multicolumn{3}{|l|}{ Attitude to risk } \\
\hline Weak & 68 & 34.0 \\
\hline Strong & 132 & 66.0 \\
\hline \multicolumn{3}{|l|}{ Imitation of a reference group } \\
\hline Weak & 80 & 40.0 \\
\hline Strong & 120 & 60.0 \\
\hline \multicolumn{3}{|l|}{ Family Support } \\
\hline Weak & 119 & 59.5 \\
\hline Strong & 81 & 40.5 \\
\hline \multicolumn{3}{|l|}{ The role of BPJS Health cadres } \\
\hline Active & 81 & 40.5 \\
\hline Passive & 119 & 59.5 \\
\hline \multicolumn{3}{|l|}{ Compliance in paying } \\
\hline Low & 91 & $45 \cdot 5$ \\
\hline High & 109 & 54.5 \\
\hline \multicolumn{3}{|l|}{ Willingness to pay } \\
\hline Low & 123 & 61.5 \\
\hline High & 77 & 38.5 \\
\hline
\end{tabular}

Table 3 displays the results of the univariate analysis with dichotomous data. Based on the table above, $92 \%$ of the study subjects were of productive age and $8 \%$ were non-productive. Most of the study subjects, as many as 140 people do not attend school or less than junior high school, and 60 others have high school to tertiary education levels.
The occupational categories of the study subjects were informal workers, namely as many as $77.5 \%$ or 155 people and 45 other people had formal jobs. The amount of the regional minimum wage (UMR) in Jember Regency in 2019 is Rp. $2,170,917$, it is known that 142 people have wages less than the UMR and 58 others 
have wages above the UMR in Jember Regency.

A total of 120 study subjects had a large number of family members, namely $3^{-}$ 6 people. While the other 80 people have 12 family members. A total of 157 research subjects stated that they rarely experience pain, on the other hand 43 other people often experience illness.

The attitude towards risk of the study subjects showed that 132 people were willing to take risks and 68 people avoided risks. The imitation of the reference group was divided into 2 categories, namely weak and strong. Most of the research subjects chose to follow the attitude of a high group of 120 people and 80 others did not follow the reference group.

Family support from study subjects was mostly lacking, namely as many as 119 people and as many as 81 people received

Table 4. Bivariate analysis of the relationship of various variables to the willingness to pay the BPJS Health premium

\begin{tabular}{|c|c|c|c|c|c|c|c|c|}
\hline \multirow{2}{*}{ Variable } & \multicolumn{2}{|c|}{ High } & \multicolumn{2}{|c|}{ Low } & \multicolumn{2}{|c|}{ Total } & \multirow[t]{2}{*}{$\mathbf{O R}$} & \multirow[t]{2}{*}{$\mathbf{p}$} \\
\hline & $\mathbf{N}$ & $\%$ & $\mathbf{N}$ & $\%$ & $\mathbf{N}$ & $\%$ & & \\
\hline \multicolumn{9}{|l|}{ Education } \\
\hline$<$ SHS & 32 & 22.86 & 108 & 77.14 & 140 & 100 & \multirow{2}{*}{21.96} & \multirow{2}{*}{$<0.001$} \\
\hline$\geq \mathrm{SHS}$ & 45 & 75.00 & 15 & 25.00 & 60 & 100 & & \\
\hline \multicolumn{9}{|l|}{ Income } \\
\hline$<$ minimum wage & 40 & 28.17 & 102 & 71.83 & 142 & 100 & \multirow{2}{*}{9.07} & \multirow{2}{*}{$<0.001$} \\
\hline$\geq$ minimum wage & 37 & 63.79 & 21 & 36.21 & 58 & 100 & & \\
\hline
\end{tabular}

Table 4 presents the results of the bivariate analysis of the relationship between education level and income on the willingness to pay for BPJS Health participants.

\section{a. The relationship between the willingness to pay the BPJS Health premium and education}

The results of the analysis show that there is a relationship between the level of education and the willingness to pay the BPJS Health premium. BPJS Kesehatan participants who have a higher education strong family support. A total of 119 people considered the role of BPJS Health cadres in Jember Regency to be less active, while 81 others considered the role of BPJS Health cadres in Jember Regency to be active.

A total of 109 study subjects had strong compliance with paying, while 91 others had weak compliance with paying premiums. Meanwhile, the willingness to pay premiums from the research subjects was low, namely 123 people, and 77 people or $38.5 \%$ others had a high willingness to pay.

\section{Bivariate Analysis}

Bivariate analysis in this study aims to explain the relationship between the independent variable and the dependent variable. Bivariate analysis can be seen in table 4 as follows: 
Nurlia et al./ Willingness and Compliance to Pay National Health Insurance Premium

BPJS Kesehatan participants who have low incomes are 4.49 times more likely to be willing to pay the premium compared to BPJS Kesehatan participants who have high incomes. It can be concluded that there is a

Table 5 Bivariate analysis of the relationship between various variables on compliance with paying BPJS Health premiums

\begin{tabular}{|c|c|c|c|c|c|c|c|c|}
\hline \multirow{2}{*}{ Variable } & \multicolumn{2}{|c|}{ High } & \multicolumn{2}{|c|}{ Low } & \multicolumn{2}{|c|}{ Total } & \multirow{2}{*}{$\mathbf{O R}$} & \multirow[b]{2}{*}{$\mathbf{p}$} \\
\hline & $\mathbf{N}$ & $\%$ & $\mathbf{N}$ & $\%$ & $\mathbf{N}$ & $\%$ & & \\
\hline \multicolumn{9}{|l|}{ Willingness to pay } \\
\hline Low & 51 & 41.46 & 72 & 58.54 & 123 & 100 & \multirow{2}{*}{$4 \cdot 31$} & \multirow{2}{*}{$<0.001$} \\
\hline High & 58 & $75 \cdot 32$ & 19 & 24.68 & 77 & 100 & & \\
\hline \multicolumn{9}{|c|}{$\begin{array}{l}\text { Imitation of a reference } \\
\text { group }\end{array}$} \\
\hline Weak & 32 & 40.00 & 48 & 60.00 & 80 & 100 & \multirow{2}{*}{2.69} & \multirow{2}{*}{$<0.001$} \\
\hline Sttrong & 77 & 64.17 & 43 & 35.83 & 120 & 100 & & \\
\hline \multicolumn{9}{|c|}{ Number of family member } \\
\hline Low & 35 & 43.75 & 45 & 56.25 & 80 & 100 & \multirow{2}{*}{2.07} & \multirow{2}{*}{0.013} \\
\hline High & 74 & 61.67 & 46 & 38.33 & 120 & 100 & & \\
\hline
\end{tabular}

Table 5 presents the results of the bivariate analysis of the willingness to pay, imitation of the referral group, and the number of family members on the payment compliance of BPJS Kesehatan participants.

\section{a. Relationship between BPJS Health premium payment compliance and willingness to pay}

The results of the analysis show that there is a relationship between the willingness to pay premiums and compliance with BPJS Health premiums. BPJS Kesehatan participants who have a high willingness to pay premiums are 4.31 times more likely to comply with premiums than BPJS Kesehatan participants who have a low willingness to pay premiums. It can be concluded that there is a significant relationship between premium payment compliance with BPJS Health premium payment compliance.

\section{b. Relationship between BPJS Health premium payment compliance and referral group imitation}

The results of the analysis show that there is an imitation relationship between the significant relationship between the level of income and the willingness to pay the BPJS Health premium. referral group and BPJS Health premium payment compliance. BPJS Kesehatan participants who have a strong imitation referral group are 2.69 times more likely to comply with paying the premium compared to BPJS Kesehatan participants who have a weak reference group imitation. It can be concluded that there is a significant relationship between the imitation of the referral group and the compliance with BPJS Health premiums.

c. The relationship between BPJS health premium payment compliance and the number of family members

The results of the analysis show that there is a relationship between the number of family members and compliance with BPJS Health premiums. BPJS Kesehatan participants who have a large number of family members ( $\geq 3$ people) are 2.07 times more likely to comply with paying the premium compared to BPJS Kesehatan participants who have a low number of family members. It can be concluded that there is a significant relationship between the number of 
Nurlia et al./ Willingness and Compliance to Pay National Health Insurance Premium

family members and compliance with BPJS

Kesehatan premiums.

\section{Multivariate Analysis}

Multivariate analysis is used to describe the effect of each independent variable simultaneously on the dependent variable.

Table 6. Results of multiple linear regression analysis of Willingness to pay BPJS Health premium

\begin{tabular}{lcccc}
\hline \multirow{2}{*}{ Independent Variable } & \multirow{2}{*}{$\mathbf{b}$} & \multicolumn{2}{c}{$\mathbf{9 5 \%}$ CI } & \multirow{2}{*}{ p } \\
\cline { 3 - 4 } & & Lower Limit & Upper Limit & \\
\hline Education (High) & 45531.18 & 35335.1 & 55727.26 & $<0.001$ \\
Income (Low) & 17469 & 7171.90 & 27766.09 & $<0.001$ \\
\hline
\end{tabular}

\section{b. Multiple Logistic Regression Analysis}

Table 7. Results of multiple logistic regression analysis of compliance with paying BPJS Health premiums

\begin{tabular}{lcccc}
\hline \multirow{2}{*}{ Independent Variable } & \multirow{2}{*}{ OR } & \multicolumn{2}{c}{ 95\% CI } & \multirow{2}{*}{ p } \\
\cline { 3 - 4 } & & Lower Limit & Upper Limit & \\
\hline Willingness to pay & 4.19 & 2.19 & 8.04 & $<0.001$ \\
Education (High) & 2.59 & 1.39 & 4.85 & 0.003 \\
Imitation of a reference group & 1.90 & 1.02 & 3.56 & 0.044 \\
\hline
\end{tabular}

Table 6 presents the results of multiple linear regression analysis of the effect of education level and income on the willingness to pay for BPJS Health participants. The level of education shows an effect on the willingness to pay the BPJS Health premium and is statistically significant. Independent BPJS Kesehatan participants who have a higher education level increase the willingness to pay by 45531.18 units, higher than the independent BPJS Kesehatan participants who have a low education level $(b=45531.18 ; 95 \% \mathrm{CI}=35335.1$ to 55727.26; $\mathrm{p}<0.001$ ).

The income level shows an effect on the willingness to pay the BPJS Health premium and is statistically significant. Independent BPJS Kesehatan participants who have low income increase their willingness to pay by 17469 units, higher than BPJS Kesehatan independent participants who have low income $(b=17469 ; 95 \% \mathrm{CI}=$ 7171.90 to 27766.09; $\mathrm{p}<0.001)$.

\section{a. Multiple linear regression analysis} Multiple linear regression test in this study was to determine the effect of the independent variable on the dependent variable. 
Nurlia et al./ Willingness and Compliance to Pay National Health Insurance Premium

rence group imitations $(b=2.59 ; 95 \% \mathrm{CI}=$ 1.39 to $4.85 ; \mathrm{p}=0.003)$.

The number of family members shows an influence on the compliance of paying the BPJS Health premium. Independent BPJS Kesehatan participants who have a high number of family members increase pay compliance by 1.90 times higher than the independent BPJS Kesehatan partici-

Table 8 results of the path analysis of willingness and compliance to pay the BPJS Health premium

\begin{tabular}{|c|c|c|c|c|c|}
\hline \multirow[b]{2}{*}{$\begin{array}{l}\text { Dependent } \\
\text { Variable }\end{array}$} & \multirow[b]{2}{*}{ Independent Variable } & \multirow[b]{2}{*}{ b } & \multicolumn{2}{|c|}{$95 \% \mathrm{CI}$} & \multirow[b]{2}{*}{$\mathbf{p}$} \\
\hline & & & $\begin{array}{l}\text { Upper } \\
\text { Limit }\end{array}$ & $\begin{array}{c}\text { Lower } \\
\text { Limit }\end{array}$ & \\
\hline \multicolumn{6}{|l|}{ Direct Effect } \\
\hline \multirow[t]{2}{*}{$\begin{array}{l}\text { Willingness to } \\
\text { pay }\end{array}$} & $\leftarrow$ Education (High) & 2.13 & 1.41 & 2.86 & $<0.001$ \\
\hline & $\leftarrow$ Income (Low) & 1.19 & 0.46 & 1.92 & $<0.001$ \\
\hline \multirow{3}{*}{$\begin{array}{l}\text { Payment } \\
\text { compliance }\end{array}$} & $\leftarrow$ Willingness to pay (High) & 1.43 & 0.78 & 2.08 & $<0.001$ \\
\hline & $\begin{array}{l}\leftarrow \text { Imitation of a reference group } \\
\text { (Yes) }\end{array}$ & 0.95 & 0.33 & 1.58 & 0.003 \\
\hline & $\begin{array}{l}\leftarrow \text { Number of family member } \\
\quad(\geq 3 \text { people })\end{array}$ & 0.64 & 0.02 & 1.27 & 0.044 \\
\hline $\begin{array}{l}\text { N observation }= \\
\log \text { likelihood }=-\end{array}$ & 0 & & & & \\
\hline
\end{tabular}

\section{a) Willingness to pay}

The level of education shows an effect on the willingness to pay the BPJS Health premium and is statistically significant. Independent BPJS Kesehatan participants who have a high level of education towards health needs will increase the willingness to pay logodd by 2.13 units, higher than BPJS Kesehatan independent participants who have a low level of education $(b=2.13$; 95\% $\mathrm{CI}=1.41$ to 2.86 ; $\mathrm{p}<0.001$ ).

There is a large effect of income on the willingness to pay BPJS Kesehatan premiums and it is statistically significant. Independent BPJS Kesehatan participants who have low income for health service needs will increase the willingness to pay logodd by 1.19 units, higher than BPJS Kesehatan independent participants who have high income for health service needs (b = 1.19; 95\% CI = 0.46 to $1.92 ; \mathrm{p}<0.001$ ) . pants who have a low number of family members $(b=1.90 ; 95 \% \mathrm{CI}=1.02$ to 3.56 ; $\mathrm{p}=0.044)$.

\section{c. Path Analysis}

Table 8 shows that there is an influence on the two dependent variables, namely willingness to pay and pay compliance.

\section{b) Compliance with payments}

There is an effect of the willingness to pay the BPJS Health premium on the compliance to pay the BPJS Health premium and it is statistically significant. Independent BPJS Kesehatan participants who have a willingness to pay a high BPJS Health premium on the need for health services will increase the compliance logodd of paying by 1.43 units higher than the independent BPJS Kesehatan participants who have a willingness to pay a low BPJS Health premium for health service needs $(b=1.43$; 95\% $\mathrm{CI}=0.78$ to 2.08; $\mathrm{p}<0.001$ ).

There is an effect of referral group imitation on compliance with BPJS Health premiums and it is statistically significant. Independent BPJS Kesehatan participants who have strong reference group imitations towards health service needs will increase the compliance logodd to pay by 0.05 units 
higher than BPJS Kesehatan participants who have weak reference group imitations towards health service needs $(b=0.95 ; 95 \%$ $\mathrm{CI}=0.33$ to $1.58 ; \mathrm{p}=0.003$ ).

There is an effect of the number of family members on compliance to pay the BPJS Health premium and it is statistically significant. BPJS Kesehatan independent participants who have a large number of family members ( $\geq 3$ people) with regard to the need for health services will increase the logodd of paying compliance by 0.64 units, higher than BPJS Kesehatan independent participants who have a low number of family members towards health service needs $(b=0.64 ; 95 \% \mathrm{CI}=0.02$ to 1.27 ; $\mathrm{p}=0.044)$.

\section{DISCUSSION}

\section{The effect of education on the} willingness to pay

The results of this study indicate that there is an effect between education on the willingness to pay the BPJS Health premium. It is known that the coefficient value (b) is positive, so the effect of education on the willingness to pay the BPJS Health premium is a positive and statistically significant effect. This is in line with Azhar et al. (2018) which states that the level of education has a positive effect on the willingness to pay. Research subjects in Sarawak with a higher level of education were 2.42 times more likely to pay for health insurance.

According to Zhai et al. (2017), education is one of the factors that affects the knowledge of health insurance needed according to the conditions. The types and benefits of health insurance have been shown to increase the perception of equality and the high benefits that can be obtained from the national health care system in China. It is known from the results of data analysis that it shows a significant effect.
Adewole et al. (2017) showed that the educational status of the research subjects was the only predictor significantly associated with NHIS awareness. Research subjects with post-primary education have 10 times the chance of knowing NHIS than research subjects who have no education or only basic education.

\section{The effect of income on WTP}

The results of this study indicate that there is a direct influence between income and the willingness to pay the premium of BPJS Kesehatan Mandiri. It is known that the coefficient value (b) is positive, so the effect of income on the willingness to pay the premium for BPJS Kesehatan Mandiri is statistically significant.

This is in line with Witati and Putri's (2020), which states that income has a positive relationship with willingness to pay. This means that the higher the family income, the higher the likelihood that informal workers will be willing to pay contributions from the Healthcare Social Security Administration (BPJS) assuming other factors are considered constant.

Thi et al. (2018) stated that there is a relationship between financial support (family member income) and the decision of the head of the household to be willing to pay for social insurance. The study shows that $48.8 \%$ of 391 households working in the informal sector with a high family income are willing to pay 921.9 thousand Vietnamese dong per household per year (US \$ 42) for social insurance in Vietnam.

In line with Ashari and Nurhayani's (2013), the level of income of a family is determined by family work and skills. High income levels will tend to choose the services to be used. However, this is not the case with people who have low income levels, basic needs are the main interest and health insurance is a need that is met after basic needs are met. 


\section{The effect of willingness to pay on pay compliance}

The results of this study indicate that there is an influence between the willingness to pay on the compliance of paying BPJS Kesehatan Mandiri premiums. It is known that the coefficient value (b) is positive, so the effect of willingness to pay on compliance with BPJS Kesehatan Mandiri premiums is statistically significant.

According to Widyanti (2018), compliance in paying dues means the behavior of a person who is willing to pay dues appropriately based on a predetermined time. Compliance with paying dues can increase the collectivity of BPJS Kesehatan.

In line with Sunjaya et al. (2020), compliance with paying premiums in lowincome communities is generally low. Participants classified as poor and vulnerable to poor should be registered as beneficiaries. As a result, participants are unable to pay contributions. A person's compliance is influenced by one's intention to pay contributions.

Workneh et al. (2017) show that the willingness of household members to renew (94.5\%) CBHI membership is one of the predictors of member compliance, with a strong positive statistical association. The level of compliance of members to CBHI regulations is quite good at the program implementation stage.

\section{Effect of reference group imitation on pay compliance}

The results of this study indicate that there is an influence between the imitation of the referral group on compliance with paying BPJS Kesehatan Mandiri premiums. It is known from the value of the coefficient (b) is positive, then there is an effect of imitation of the referral group on compliance with paying BPJS Kesehatan Mandiri premiums which is statistically significant.
According to Fadlallah et al. (2018), when community members feel solidarity in paying the premium, other members are more likely to join the scheme. Community solidarity can demonstrate demonstration of community behavior.

This is in line with Puspitasari (2017), which shows that the closest people and peers have an important role in influencing someone tofollow the JK program through information about $\mathrm{JK}$. The role of this behavior can be used as a model for compliance with BPJS Health premiums.

According to research conducted by Barida, (2016) imitation behavior is someone's behavior by imitating what he interprets through observation of a model that becomes the object of his observation. A person performs the principle of imitating an action by understanding the objectives of the action and directed by the achievement of the target goals.

\section{The effect of the number of family members on pay compliance}

The results of this study indicate that there is an influence between the number of family members on compliance with paying BPJS Kesehatan Mandiri premiums. It is known from the value of the coefficient (b) is positive, so the effect of the number of family members on compliance with BPJS Kesehatan Mandiri premiums is statistically significant.

According to Witati and Putri (2020), the more the number of family members, the more the household needs to meet the needs of life. The impact faced is that the larger the number of family members, the more premiums must be paid.

This is in line with Adebayo et al. (2015) which states that they find that in the CBHI scheme larger households are willing to pay a higher amount than relatively smaller households. If larger households exit the scheme this is likely 
due to the enormous financial burden that households face when they seek health care.

According to Sunjaya et al. (2020) non-compliance in paying contributions is caused by the large number of family members that the head of the family must bear. The greater the number of family members, the larger the number of contributions that must be paid. People feel that if someone is not sick too often, there is no need for routine expenses. In addition, they feel that the cost of accessing health services is still affordable.

\section{AUTHOR CONTRIBUTION}

Nazilla Ade Nurlia as the main researcher played a role in coordinating the research, conducting all stages of the research, and completing the research paper. Bhisma Murti plays a role in developing ideas, research designs, research frameworks, and research data processing. Didik Gunawan Tamtomo played a role in suggesting research discussions and writing techniques.

\section{CONFLICT OF INTEREST}

There is no conflict of interest.

\section{FUNDING AND SPONSORSHIP}

This study is self-funded.

\section{ACKNOWLEDGEIMENT}

Our gratitude goes to BPJS Kesehatan Kabupaten Jember for allowing this research to be carried out. Thank you to the BPJS Kesehatan participants who participated and were willing to be respondents in the research.

\section{REFERENCE}

Adebayo EF, Uthman OA, Wiysonge CS, Stern EA, Lamont KT, Ataguba JE (2015). A systematic review of factors that affect uptake of community- based health insurance in low-income and middle- income countries. BioMed Central. 15(543). doi: 10.1186/s12913-015-1179-3.

Ashari MR, Nurhayani (2013). Permintaan (demand) masyarakat terhadap pemanfaatan asuransi kesehatan di PT (Public demand for the use of health insurance at PT). Asuransi Jiwa In Health Makassar. Jurnal MKMI. 5359. Available at: https://media.neliti.com/media/publications/212592-none.pdf.

Azhar A, Rahman MM, Arif MT (2018). Willingness to pay for health insurance in Sarawak, Malaysia: A contingent valuation method. Bangladesh Journal of Medical Science. 17(2): 230-237. doi: 10.3329/bjms.v17i2.35876.

Barida M (2016). Pengembangan perilaku anak melalui imitasi (Development of children's behavior through imitation). Jurnal CARE Edisi Khusus Temu Ilmiah. 03(3): 13-20. Retrieved fromhttp://e-journal.unipma.ac.id/index.php/JPAUD/article/view/594

BPJS Kesehatan (2019). Data peserta progam JKN (JKN program participant data). Retrieved from https://bpjskesehatan.go.id/.../b39df9ae7a30a5c 7d4bdof54d763b447.pdf

Fadlallah R, El-jardali F, Hemadi N, Morsi RZ, Samra CAA, Ahmad A, Arif K, Hishi L, Honein-abouhaidar G, Akl EA (2018). Barriers and facilitators to implementation, uptake and sustainability of community- based health insurance schemes in low- and middle-income countries: a systematic review. Int J Equity Health. 17(13): 118. doi: 10.1186/s12939-018-0721-4.

Mas'udin (2017). Identifikasi permasalahan finansial pada jaminan sosial kesehatan nasional (Identification of 
Nurlia et al./ Willingness and Compliance to Pay National Health Insurance Premium

financial problems in national health social security). Jurnal Info Artha. 1(2): 111-119. doi: 10.31092/jia.v1i2.142.

Nguyen LH, Hoang ATD (2017). Willingness to pay for social health insurance in central Vietnam. Front public health. 5(APR): 1-7. doi: 10.3389/FPUBH.2017.00089.

Noormalasari W, Sandra C (2015). Kemampuan membayar iuran jaminan kesehatan nasional bagi nelayan di kabupaten Jember (Ability to pay national health insurance contributions for fishermen in Jember district). e-Jurnal Pustaka Kesehatan.3(1): 147-154.

Prakoso AD (2020). Analisis jalur determinan partisipasi pekerja informal pada progam jaminan kesehatan di Kabupaten Kudus (Analysis of the determinant pathway for the participation of informal workers in the health insurance program in Kudus Regency). Program Ilmu Kesehatan Masyarakat, Program Pascasarjana, Universitas Sebelas Maret.

Rosmanely S (2018). Studi ketidakpatuhan membayar iuran bpjs kesehatan peserta non pbi bukan penerima upah di kelurahan parang tambung kec. Tamalate (The study of non-compliance with paying bpjs health fees for non-pbi participants who did not receive wages in the Parang Tambung district). Administrasi Kebijakan Kesehatan. Universitas Hasanuddin. Retrieved from http://digilib.unhas. ac.id/uploaded_files/temporary/DigitalCollection/MGNjYTEyN2ZiYjI4Yzlj NWE2ZGMoODZkMTdhNjNlNDM4Y jQ3MDg4ZA==.pdf.

Sunjaya DK, Herawati DMD, Siregar AY (2020). Factors affecting independent participants of Indonesia's national health insurance in paying premium compliance: a qualitative study. (38): 1-32. doi: 10.21203/rs.3.rs-26637/v1.

Thi N, Nga T, Fitzgerald G, Dunne M (2018). Family-based health insurance for informal sector workers in Vietnam: why does enrolment remain low?. Asiapac J public health. 1-9. doi: 10.1177/1010539518807601.

Widyanti N (2018). Faktor yang berhubungan dengan kepatuhan membayar iuran BPJS Kesehatan mandiri pada pasien di rsud labuang baji kota Makassar. Hasanuddin Makassar. Retrieved from http://digilib.unhas.ac.id/uploaded_files/temporary/DigitalCollection/NTVkYzIxMDYzM2IoYTViYTgzOGZlYzgwNjI3OWQ1OTEoN2M2ZTRkMw==.pdf.

Witati, Putri PI (2020). Determinant of willingness to pay health insurance contribution to informal workers. Economics Development Analysis Journal, 9(2): 144-158. Retrieved from: https://journal.unnes.ac.id/sju

/index.php/edaj/article/view/38440

Workneh SG, Biks GA, Woreta SA (2017). Community-based health insurance and communities scheme requirement compliance in Thehuldere district, northeast Ethiopia: cross-sectional community-based study. Dove Med Journal. 353-359. doi: 10.2147/CEOR.S136508.

Zhai S, Wang P, Dong Q, Ren X, Cai J, Coyte PC (2017). A study on the equality and benefit of China's national health care system. Int J Equity Health. 16 (155): 1-11. https://doi.org/10.1186/s12939017-0653-4. 